\title{
Thermal-Oxidative Pretreatment and Evaluation of Poly(Hexafluoropropene Oxide) Fluids
}

K.J.L. Paciorek, S.R. Masuda, and W-H. Lin

Technolube Products Co.

Vernon, California

W.R. Jones, Jr.

Lewis Research Center

Cleveland, Ohio

L.S. Helmick

Cedarville College

Cedarville, Ohio

Prepared for the

Tribology Conference

cosponsored by the Society of Tribologists and Lubrication Engineers

and the American Society of Mechanical Engineers

Lahaina, Hawaii, October 16-19, 1994
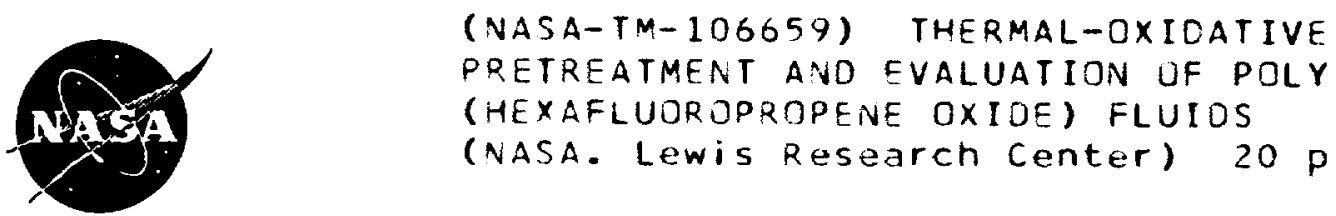
...

, 


\title{
THERMAL-OXIDATIVE PRETREATMENT AND EVALUATION OF POLY(HEXAFLUOROPROPENE OXIDE) FLUIDS
}

\author{
by \\ K.J.L. Paciorek, S.R. Masuda, W-H. Lin \\ Technolube Products Co. \\ Los Angeles, California \\ William R. Jones, Jr. \\ National Aeronautics and Space Administration \\ Lewis Research Center \\ Cleveland, Ohio 44135 \\ and \\ Larry S. Helmick ${ }^{1}$ \\ Cedarville College \\ Cedarville, Ohio
}

\begin{abstract}
Two commercial poly(hexafluoropropene oxide) fluids were thermally pretreated at $343^{\circ} \mathrm{C}$ in pure oxygen. IR and NMR spectra indicate that this pretreatment was effective in removing hydrogen end-capped impurities. Decrease in the quantity of volatile material produced during thermal oxidative decomposition and increase in the thermal decomposition temperature indicated improvement in the stability of the fluids. However, this pretreatment failed to render the fluids completely stable in oxidizing atmospheres at $316^{\circ} \mathrm{C}$ in the presence of metal alloys.
\end{abstract}

\section{INTRODUCTION}

Perfluoropolyalkylethers (PFPAE) represent a class of liquid lubricants which have been used for space applications for over 30 years (1), (2). In addition, these fluids are promising candidates for high temperature aeronautical applications (3) - (5). One member of this class based on poly(hexafluoropropene oxide)(HFPO) has been commercially available for many years (6).

Poly(HFPO) fluids have been studied extensively. These studies include: thermal stability (7), oxidative stability (8), stability in the presence of Lewis acids (9) - (13), viscoelastic behavior (14), elastohydrodynamic behavior (15), pressure-viscosity characteristics (16), time-of-flight secondary ion mass spectroscopy (17), (18), electron beam (19) and $x$-ray damage (20), surface migration (21), and conformation (22) and tribochemical degradation (12), (23), (24).

Thermal stability, in the absence of catalytic surfaces and oxygen, for poly(HFPO) fluids has been shown to range from 356 to $376^{\circ} \mathrm{C}$ depending on molecular weight (7). Although these stabilities are similar to other members of the PFPAE class, they certainly do not represent the ultimate stability of the poly(HFPO) polymers. For example, Gumprecht (25) has reported thermal stabilities for very pure research grade HFPO polymers of $410^{\circ} \mathrm{C}$ using an isoteniscope. This 30 to $50^{\circ} \mathrm{C}$ difference has usually been attributed to the presence of small amounts (ppm) of thermally labile impurities. These impurities may take the form of hydrogen end-capped chains, peroxides, carbonyl groups, or other arrangements not represented by the usual HFPO structure.

Of all of these impurities, hydrogen end-capped chains $\left(-\mathrm{OCHFCF}_{3}\right)$ are most prevalent. This group is easily detected by Fourier Transform Infrared Spectroscopy (FT-IR) (18), proton Nuclear Magnetic Resonance (NMR) (26), and Time-Off-Flight Secondary Ion Mass Spectroscopy (TOF-SIMS) (18). Typically, commercial poly(HFPO) fluids contain from 1 to $5 \mathrm{ppm}$ by weight of hydrogen. Although this appears to be a rather small amount, it does represent approximately 1 to 3 percent of the chains, depending on molecular weight.

\footnotetext{
${ }^{1}$ Summer Faculty Fellow at NASA Lewis Research Center.
} 
Stabilization of poly(HFPO) fluids by removing these hydrogen end-capped chains appeared to be a viable procedure. These chains can be removed by exhaustive fluorination or by simply treating the fluid at high temperature with oxygen (8). However, this earlier work (8) did not address the structural changes taking place during pretreatment and only involved one batch of fluid (MLO-71-6).

Therefore, the objective of this study was to thermally pretreat two new batches of poly(HFPO) fluids in oxygen in order to determine if pretreatment results in more stable fluids in the presence of catalytic surfaces for currently produced materials. In addition, proton NMR, $\mathrm{F}^{19} \mathrm{NMR}$, and FT-IR were used to determine structural changes. Improvement in stability was determined by measuring the volatiles produced during thermal-oxidative degradation, and confirmed by measuring the thermal decomposition temperature $\left(T_{d}\right)$ with a tensimeter (7).

\section{EXPERIMENTAL}

Fluids

Two commercial poly(HFPO) fluids, 143AC (Batch 53538-29-2) and 143AB (Batch 42420-13), were tested. Henceforth, these fluids will be referred to as $\mathrm{AC}$ and $\mathrm{AB}$. The fluids had essentially an identical chemical structure but differed in molecular weight and viscosity (Table 1, Footnote 2).

\section{Thermal-Oxidative Pretreatment}

Fluids ( -28 to $31 \mathrm{~g}$ samples) were stabilized by heating in oxygen at $343^{\circ} \mathrm{C}$ for the time periods shown in Table 1 (Tests 3, 4, 8, and 9). Duplicate pretreatments of the fluids were performed in order to assure adequate oxygen supply and to demonstrate test repeatability (e.g. Tests 3 and 4). The pretreatment was conducted in two steps ( $a$ and $b$ ) with data obtained after each step. Data are reported in Table $I$.

\section{Thermal-Oxidative Degradation Apparatus and Procedure}

Success of the pretreatment was evaluated by conducting thermal-oxidative degradation tests with $\mathrm{Ti}(4 \mathrm{Al}$, $4 \mathrm{Mn}$ ) alloy in oxygen at $316^{\circ} \mathrm{C}$ for $24 \mathrm{hr}$ and comparing the results to those obtained for the untreated fluids.

The thermal-oxidative degradation apparatus appears in Fig. 1. In a typical experiment the fluid was introduced into the degradation tube which was then evacuated and filled at a known temperature with oxygen. Since the apparatus was calibrated and the fluid volume measured, the quantity of oxygen introduced was exactly known. The degradation tube was then inserted into a box furnace for a specified time; throughout this exposure the temperature was continuously recorded. After removal from the furnace the tube was allowed to cool to room temperature, attached to the high-vacuum line, and opened. The liquid-nitrogen condensibles, which were volatile at room temperature, were collected and weighed. The fluid residue itself was weighed and, in some cases, subjected to viscosity determinations. The results are summarized in Table 1.

Metal catalysts were in the form of disks, $9.5 \mathrm{~mm}$ o.d., $3.2 \mathrm{~mm}$ i.d., and 0.94 to $1.27 \mathrm{~mm}$ thick. Prior to testing, the metal disks were polished using finishing paper followed by open-coated silicon carbide paper grades 400 and 500A. Subsequently, the disks were washed in trichlorotrifluoroethane (TCF), dried, weighed, and suspended in the test apparatus. For more details on this test procedure, refer to Ref. 8.

\section{Thermal Stability Apparatus and Procedure}

Recently, a thermal stability apparatus (computerized tensimeter) was used to compare stabilities of a variety of PFPAE fluids (7). This device is particularly sensitive to low impurity levels. Therefore, thermal decomposition temperatures $\left(T_{d}\right)$ were determined for the fluids after treatment and compared to those of the untreated fluids in order to determine the extent of improvement in thermal stability due to removal of impurities.

The tensimeter measures isothermal rates of pressure rise (during a 144 second time interval) from which thermal decomposition temperatures $\left(T_{d}\right)$ (in the absence of oxygen and catalytic surfaces) are determined. Test repeatability is $\pm 2{ }^{\circ} \mathrm{C}$. $T_{d}$ is defined as the temperature at which $\log \mathrm{dP} / \mathrm{dt}$ equals 0.3 . A schematic representation of this device is shown in Fig. 2. The device consists of a sample cell assembly, an oven, a temperature programmer, temperature and pressure measuring components, and a data acquisition system. A detailed description of this apparatus and procedure appears in Ref. 7. A typical example of the determination of $T_{d}$ of a poly(HFPO) fluid appears in Fig. 3.

\section{Analysis}

Proton Nuclear Magnetic Resonance ( $200 \mathrm{mHz}$ ) (NMR) spectra were obtained on 40 percent solutions of the fluids in TCF. All chemical shifts are relative to TMS (tetramethylsilane) at $0 \mathrm{ppm}$. ${ }^{19} \mathrm{~F} \mathrm{NMR}$ spectra 
(188 $\mathrm{mHz}$ ) were obtained on 40 percent solutions of the fluids in $\mathrm{C}_{6} \mathrm{~F}_{6}$. Chemical shifts are reported relative to fluorotrichloromethane at $0 \mathrm{ppm}$. Transmission FT-IR spectra were obtained on neat samples in a $1 \mathrm{~mm}$ cell. The lower limit of detectability of carbon-hydrogen species is $1 \mathrm{ppm}$.

AC Fluid

\section{RESULTS AND DISCUSSION}

The AC fluid, as received, was unstable as indicated by the relatively large amount of volatile material produced in the presence of $\mathrm{Ti}(4 \mathrm{Al}, 4 \mathrm{Mn})$ alloy in oxygen at $316^{\circ} \mathrm{C}$ in $24 \mathrm{hr}(231 \mathrm{mg} / \mathrm{g}$, Test 1$)$, and the relatively low thermal decomposition temperature $\left(369^{\circ} \mathrm{C}\right)$ compared to $410^{\circ} \mathrm{C}$ observed for highly purified HFPO polymers by Gumprecht using an identical technique. Therefore, duplicate samples of $\mathrm{AC}$ fluid were treated at $343^{\circ} \mathrm{C}$ with oxygen in an attempt to improve the stability (Tests 3 and 4). The "pretreatment" was conducted in two steps of 192 $\mathrm{hr}$ (a) and $96 \mathrm{hr}$ (b), resulting in a total treatment time of $288 \mathrm{hr}$. The yield of volatile material after the first step was $43.6 \mathrm{mg} / \mathrm{g}$ (Test 3a.) It should be noted that volatiles were not measured for test $4 \mathrm{a}$ after the $192 \mathrm{hr}$ treatment. However, the weight loss data for the duplicate samples (Tests 3a and 4a) corresponded closely, demonstrating good repeatability. The low volatile production, $2 \mathrm{mg} / \mathrm{g}$, following the $96 \mathrm{hr}$ treatment (Test $3 \mathrm{~b}$ and $4 \mathrm{~b}$ ), indicated completeness of the operation. The stability of the fluid was then determined.

Exposure of the fluid to $\mathrm{Ti}(4 \mathrm{Al}, 4 \mathrm{Mn})$ alloy at $316^{\circ} \mathrm{C}$ (Test 5) resulted in production of $134 \mathrm{mg} / \mathrm{g}$ of volatile material, a reduction of 42 percent compared to $230 \mathrm{mg} / \mathrm{g}$ for the untreated fluid (Test 1 ). This improvement in stability is also confirmed by the accompanying increase in $T_{d}$ from 369 to $382{ }^{\circ} \mathrm{C}$. However, production of 134 $\mathrm{mg} / \mathrm{g}$ of volatile material in Test 5 is surprisingly high when compared to MLO-71-6, a well studied poly(HFPO) fluid which, after a similar pretreatment, was stable at $316^{\circ} \mathrm{C}(4.5 \mathrm{mg} / \mathrm{g})$ in the presence of titanium alloy and oxygen (8). In addition, the $\mathrm{T}_{\mathrm{d}}$ of $382^{\circ} \mathrm{C}$ is still well below the $410^{\circ} \mathrm{C}$ observed by Gumprecht. Why is the treated fluid not more stable?

At this stage, two potential explanations can be advanced: either the hydrogen terminated chains were not completely removed or some other unusual and unstable structural arrangement was present in this fluid which was not present in the MLO-71-6 fluid. IR and NMR spectra may help to distinguish between these two possibilities.

The ${ }^{1} \mathrm{H}$ NMR spectrum of the AC fluid as received is shown in Fig. 4 (274 scans). The presence of hydrogen is evident by the doublet centered at $5.85 \mathrm{ppm}$. Following the treatment with oxygen at $343^{\circ} \mathrm{C}$ for $288 \mathrm{hr}$, no peaks in the 5.7 to $6.0 \mathrm{ppm}$ region were observed after 752 scans (Fig. 5). A similar loss of C-H absorption bands was observed in the $3000 \mathrm{~cm}^{-1}$ region of the infrared spectra (Fig. 6). Based on this data, the treatment was effective in the removal of hydrogen (or rather the removal of the hydrogen terminated chains) to less than the $1 \mathrm{ppm}$ limit of detectability. It should be noted that, based on the infrared absorption in other specific group regions before and after treatment, no chemical change in the fluid itself occurred due to the treatment. This is further supported by the lack of change in the viscosity data (Test $3 b$ ).

Figures 7 and 8 present ${ }^{19} \mathrm{~F}$ NMR spectra of the AC fluid as received, and after treatment, respectively. These were compared to the ${ }^{19} \mathrm{~F}$ spectrum of MLO-71-6 (Fig. 9). The main difference between the AC fluid, both as received and treated, and MLO-71-6 is the small, yet distinctive peak at $-76.6 \mathrm{ppm}$. Based on ${ }^{19} \mathrm{~F} \mathrm{NMR}$ spectral study of experimental PFPAE fluids, this peak may be due to a linkage of the general structure $-\mathrm{OCF}_{2} \mathrm{CF}\left(\mathrm{CF}_{2} \mathrm{OR}_{\mathrm{f}}\right) \mathrm{OCF}\left(\mathrm{CF}_{3}\right) \mathrm{CF}_{2}$. Specifically, the resonance at $-76.6 \mathrm{ppm}$ is due to the underlined $\mathrm{CF}_{2}$ adjacent to the $\mathrm{CF}$ having the $-\mathrm{CF}_{2} \mathrm{OR}_{\mathrm{f}}$ side chain. It should be mentioned that Kasai et al. (9) assigned a $-77.0 \mathrm{ppm}$ resonance to $\mathrm{FCO}-\mathrm{CF}_{2}-\mathrm{O}$ - and a signal at $-76.5 \mathrm{ppm}$ to $\mathrm{CF}_{3} \mathrm{CO}_{2} \mathrm{H}(27)$.

However, the signal at $-76.6 \mathrm{ppm}$ in the spectra of the AC fluids cannot be due to fluorines on a carbon adjacent to a carbonyl group because of the absence of carbonyl absorption bands in the $1600-1800 \mathrm{~cm}^{-1}$ region of the infrared spectrum (Fig. 10). This conclusion is supported by the absence of resonances in the ${ }^{19} \mathrm{~F}$ NMR spectra at $-12.7,13.0$ and $23.0 \mathrm{ppm}$ due to the fluorine attached to the carbonyl carbon. (The other complex resonances in these fluids, centered around $-78 \mathrm{ppm}$, are due to $-\mathrm{OCF}\left(\mathrm{CF}_{3}\right)$ - and $-\mathrm{CF}_{2}-\mathrm{O}$ groupings (28).

Therefore, the IR and NMR spectra indicate that the residual instability in the treated AC fluid is not due to the presence of traces of hydrogen end-capped chains, but may be due to the presence of chains containing groups, such as $-\mathrm{OCF}_{2} \mathrm{CF}\left(\mathrm{CF}_{2} \mathrm{OR}_{\mathrm{f}}\right) \mathrm{OCF}\left(\mathrm{CF}_{3}\right) \mathrm{CF}_{2}$, which are not represented by the basic poly(HFPO) structural formula.

\section{AB Fluid}

The $\mathrm{AB}$ fluid was treated and analyzed similarly. The fluid, as received, was even less stable than the $\mathrm{AC}$ fluid as indicated by the larger amount of volatile materials produced $(277 \mathrm{mg} / \mathrm{g})$ when exposed to the titanium alloy in the presence of oxygen at $316^{\circ} \mathrm{C}$ for $24 \mathrm{hr}$ (Test 2) and by the lower $\mathrm{T}_{\mathrm{d}}\left(354^{\circ} \mathrm{C}\right.$ ). Treatment of duplicate samples 
of the $\mathrm{AB}$ fluid in two steps at $343^{\circ} \mathrm{C}$ with oxygen over $353 \mathrm{hr}$, using the same procedure as that employed for the AC fluid, gave similar weight losses, demonstrating good repeatability (Tests $8 \mathrm{a}$ and $9 \mathrm{a}$ ). In the first $257 \mathrm{hr}, 40.5$ $\mathrm{mg} / \mathrm{g}$ were obtained (Test $8 \mathrm{a}$ ); in the subsequent $96 \mathrm{hr}$, only $2.0 \mathrm{mg} / \mathrm{g}$ were collected (Test $8 \mathrm{~b}, 9 \mathrm{~b}$ ), indicating completeness of the pretreatment.

Following the $353 \mathrm{hr}$ treatment, the stability of the fluid in the presence of a catalytic surface was determined. The volatiles produced in the presence of the titanium alloy amounted to $55 \mathrm{mg} / \mathrm{g}$ (Test 10 ), a reduction of 80 percent compared to the untreated fluid (Test 2). A sharp increase in the $T_{d}$ from 352 to $383^{\circ} \mathrm{C}$ confirms this improvement in thermal-oxidative stability. However, a significant degree of instability still remains. Again, the IR and NMR spectra are informative.

The ${ }^{1} \mathrm{H}$ NMR spectrum of the fluid as received (Fig. 11), shows the typical doublet centered at $5.85 \mathrm{ppm}$ due to the presence of the hydrogen-terminated chains. The absence of protons in the treated fluid is shown by the ${ }^{1} \mathrm{H}$ NMR spectrum presented in Fig. 12 (800 scans). Loss of C-H absorption is also observed in the $3000 \mathrm{~cm}^{-1}$ region of the IR spectra. The ${ }^{19} \mathrm{~F}$ NMR spectrum of the AB fluid (Fig. 13) is essentially identical to that of AC fluid. However, here the resonance at $-76.6 \mathrm{ppm}$ is just barely visible as a shoulder. The assumption that this resonance may be due to the impurity causing the fluid's instability is supported by formation of a significantly smaller quantity of volatile products (a measure of the degradation extent) in the $\mathrm{AB}$ fluid (Test 10) compared to the $\mathrm{AC}$ fluid (Test 5) for treated materials. Again, $\mathbb{R}$ and NMR spectra indicated that the residual instability is not due to the presence of hydrogen-end capped impurities.

\section{CONCLUSIONS AND SUMMARY}

Thermal oxidative treatments of poly(HFPO) fluids $\mathrm{AC}$ and $\mathrm{AB}$ were effective in removal of the protoncontaining impurities. The treatment, however, failed to render the fluids stable in oxidizing atmospheres and elevated temperatures $\left(316^{\circ} \mathrm{C}\right)$ in the presence of a titanium alloy, although the degree of degradation was reduced.

\section{REFERENCES}

1. Fusaro, R.L., and Khonsari, M.M., "Liquid Lubrication for Space Applications," NASA TM-105198, July 1992.

2. Conley, P.L., and Bohner, J.J., "Experience with Synthetic Fluorinated Fluid Lubricants," 24th Aerospace Mechanisms Symposium, NASA CP-3062 (April 18-20, 1990), pp. 213-230.

3. Snyder, C.E., Jr., and Dolle, R.E., "Development of Polyperfluoroalkylethers as High Temperature Lubricants and Hydraulic Fluids," ASLE Trans., 19 (1976), pp. 171-180.

4. Snyder, C.E., Jr., Gschwender, L.J., and Tamborski, C., "Linear Polyperfluoroalkylether-Based Wide-LiquidRange High-Temperature Fluids and Lubricants," Lubr. Eng., 37 (1981), pp. 344-349.

5. Snyder, C.E., Jr., Gschwender, L.J., and Campbell, W.B., "Development and Mechanical Evaluation of Nonflammable Aerospace $\left(-54^{\circ} \mathrm{C}\right.$ to $\left.135^{\circ} \mathrm{C}\right)$ Hydraulic Fluids," Lubr. Eng., 38 (1982), pp. 41-51.

6. Gumprecht, W.H., "PR-143-A New Class of High-Temperature Fluids," ASLE Trans., 9 (1966), pp. 24-30.

7. Helmick, L.S., and Jones, W.R., Jr., "Determination of the Thermal Stability of Perfluoroalkylethers," NASA TM-102493 (1990).

8. Paciorek, K.J.L., Kratzer, R.H., Kaufman, J., and Nakahara, J.H., "Thermal Oxidative Studies of Poly(hexafluoropropene Oxide Fluids)," I. Appl. Poly. Sci. 24 (1979), pp. 1397-1411.

9. Kasai, P.H., Tang, W.T., and Wheeler, P., "Degradation of Perfluoropolyethers Catalyzed by Aluminum Oxide," Appl. Surf. Sci., 51 (1991), pp. 201-211.

10. Kasai, P.H., and Wheeler, P., "Degradation of Perfluoropolyethers Catalyzed by Aluminum Chloride," Appl. Surf. Sci. 52 (1991), pp. 91-106. 
11. Carre, D.J., and Markowitz, J.A., "The Reaction of Perfluoropolyalkylether Oil with $\mathrm{FeF}_{3}, \mathrm{AlF}_{3}$, and $\mathrm{AlCl}_{3}$ at Elevated Temperatures," ASLE Trans., 28(1) (1985), pp. 40-46.

12. Carré. D.J., "Perfluoropolyalkylether Oil Degradation: Inference of $\mathrm{FeF}_{3}$ Formation on Steel Surfaces under Boundary Conditions," ASME Trans., 29(2) (1986), pp. 121-125.

13. Zehe, M., and Faut, O., “Acidic Attack of Perfluorinated Alkyl Ether Lubricant Molecules by Metal Oxide Surfaces, STLE Trans., 33, 4 (1990), pp. 634-640.

14. Alper, T., Barlow, A.J., Gray, R.W., Kim, M.G., McLachlan, R.J., and Lamb, J., "Viscous, Viscoelastic and Dielectric Properties of a Perfluorinated Polymer. Krytox 143AB," J.C.S. Faraday II, 76 (1980), pp. 205-216.

15. Foord, C.A., Hamman, W.C., and Cameron, A., "Evaluation of Lubricants Using Optical Elastohydrodynamics," ASLE Trans., 11, 1 (1968), p. 31.

16. Jones, W.R., Jr., Johnson, R.L., Winer, W.O., and Sanborn, D.M., "Pressure-Viscosity Measurements for Several Lubricants to $5.5 \times 10^{8}$ Newtons per Square Meter $\left(8 \times 10^{4}\right.$ psi) and $140^{\circ} \mathrm{C}\left(300^{\circ} \mathrm{F}\right)$," ASLE Trans., 18, 4 (1975), pp. 249-262.

17. Fowler, D.E., Johnson, R.D., VanLeyen, D., and Benninghoven, A., "Quantitative Time-of-Flight Secondary Ion Mass Spectrometry of a Perfluorinated Polyether," Surf. and Interface Anal., Vol. 17 (1991), pp. 125-136.

18. Hues, S.M., Colton, R.J., Mowery, R.L., McGrath, K.J., and Wyatt, J.R., "Determination of Hydrogen in Perfluorinated Polyalkylethers using Time-of-Flight Secondary Ion Mass Spectrometry, Infrared Spectroscopy and Nuclear Magnetic Resonance Spectrometry," Appl. Surf. Sci., 35 (1988-89), pp. 507-519.

19. Pacansky, J., and Waltman, R.J., "Electron Beam Irradiation of Poly(perfluoroethers), Identification of Gaseous Products as a Result of Main Chain Scission," J. Phys. Chem., 95 (1991), pp. 1512-1518.

20. Mori, S., and Morales, W., "Degradation and Crosslinking of Perfluoroalkyl Polyethers under X-Ray Irradiation in Ultrahigh Vacuum," NASA TP-2910 (March 1989).

21. Novotny, VJ., "Migration of Liquid Polymers on Solid Surfaces," J. Chem. Phys. 92(5) (1990), pp. 3189-3196.

22. Novotny, V.J., Hussla, I., Turlet, J.M. and Philpott, M.R., "Liquid Polymer Conformation on Solid Surfaces," J. Chem. Phys. 90(10) (1989), pp. 5861-5868.

23. Mori, S., and Morales, W., "Tribological Reactions of Perfluoroalkyl Polyether Oils with Stainless Steel under Ultrahigh Vacuum Conditions at Rom Temperature," Wear, 132 (1989), pp. 111-121.

24. Vurens, G., Zehringer, R., and Saperstein, D., "The Decomposition Mechanism of Perfluoropolyether Lubricants during Wear." ACS Sym. Ser. 485 (1992), pp. 169-180.

25. Gumprecht, W.H., "The Preparation and Thermal Behavior of Hexafluoropropylene Epoxide Polymers," Presented at Fourth Inter. Symposium on Fluorine Chemistry, Estes Park, CO, July 1967.

26. Paciorek, K.J.L., Ito, T.I., and Kratzer, R.H., "Thermal Oxidative Degradation Reactions of Perfluoroalkylethers," NASA CR-165516 (October, 1981).

27. Kasai, P.H., "Perfluoropolyether: Intramolecular Disporportionation," Macromolecules, 25 (1992), pp. 6791-6799.

28. Ciampelli, F., Venturi, M.T., and Sianesi, D., "The ${ }^{19} \mathrm{~F}$ Chemical Shift in Oxygen-Containing Carbon Fluorine Products," Organic Magnetic Resonance, 1 (1969), pp. 281-293. 
Table 1

THERMAL OXIDATIVE TREATMENT OF POLY (HFPO) FLUIDS ${ }^{1}$

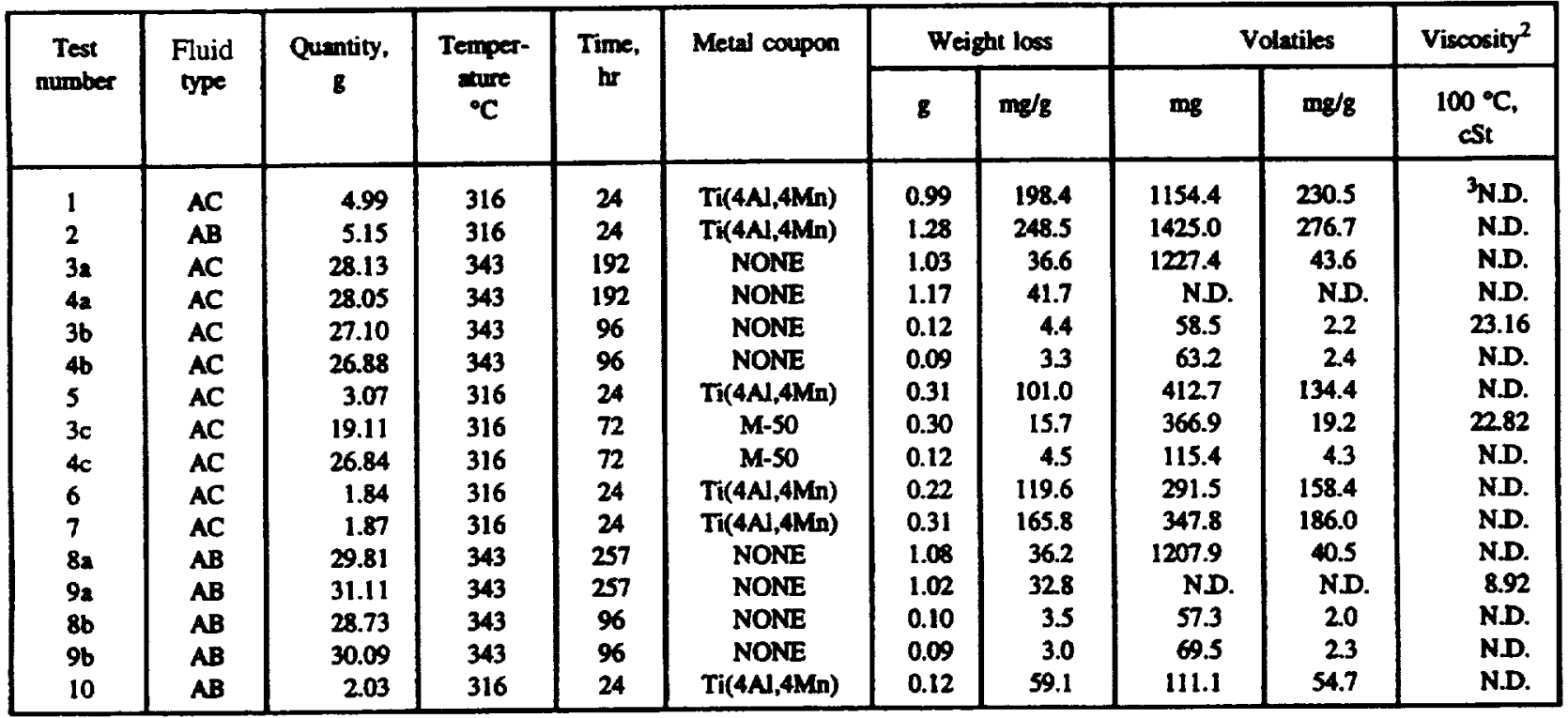

${ }^{\prime}$ All tests were performed in an amosphere of pure oxygen (approximately $5.3 \times 10^{4} \mathrm{~Pa}$ ) at the denoted temperature and period of time.

${ }^{2}$ Viscosity at $100^{\circ} \mathrm{C}$ after test. Viscosity of $\mathrm{AC}$ (Batch $\left.53538-29-2\right)$ as received was $22.60 \mathrm{cSt}$ at $100^{\circ} \mathrm{C}$. Viscosity of $\mathrm{AB}$ (Batch 42420-13) as roceived was $8.86 \mathrm{cSt}$ at $100^{\circ} \mathrm{C}$.

${ }^{3}$ N.D. = Not Done. 


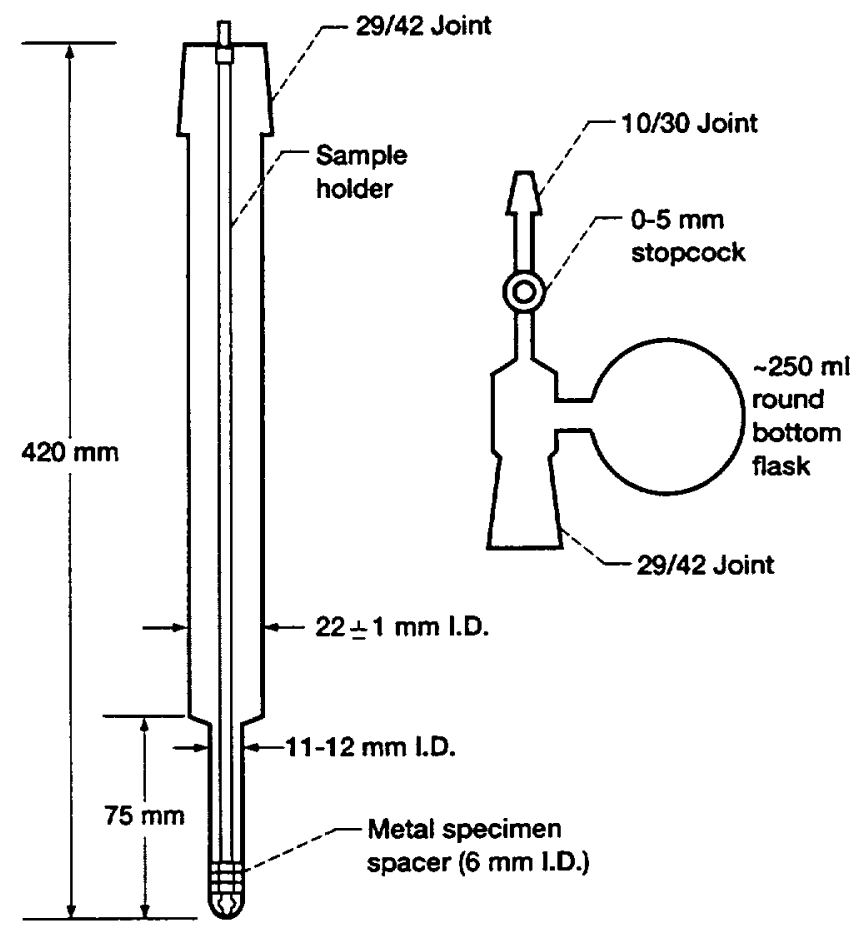

Figure 1.-Thermal-oxdative degradation apparatus.

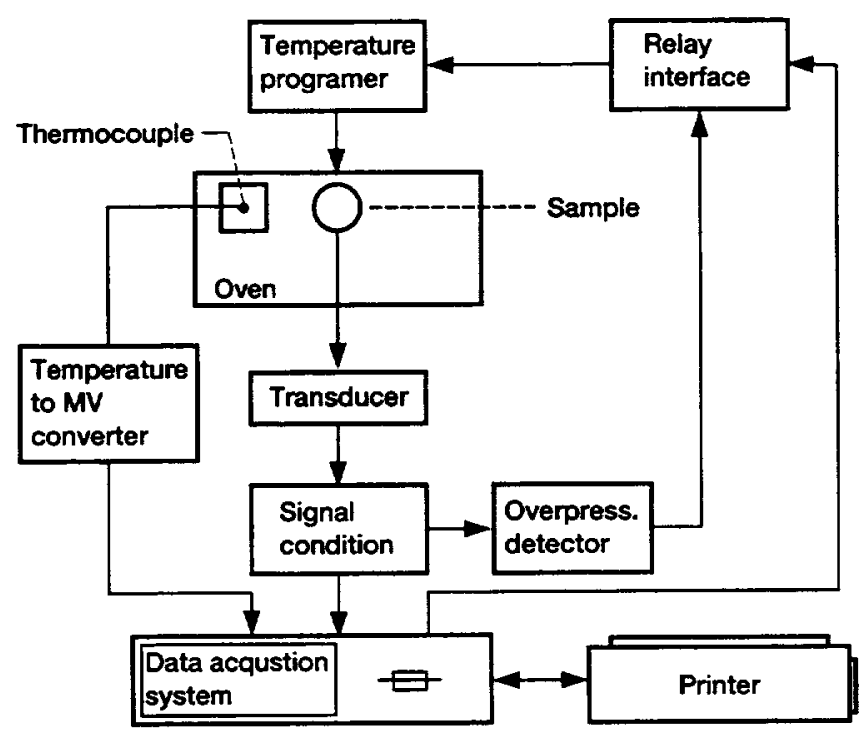

Figure 2.-Schematic diagram of thermal stability apparatus (tensimeter). 


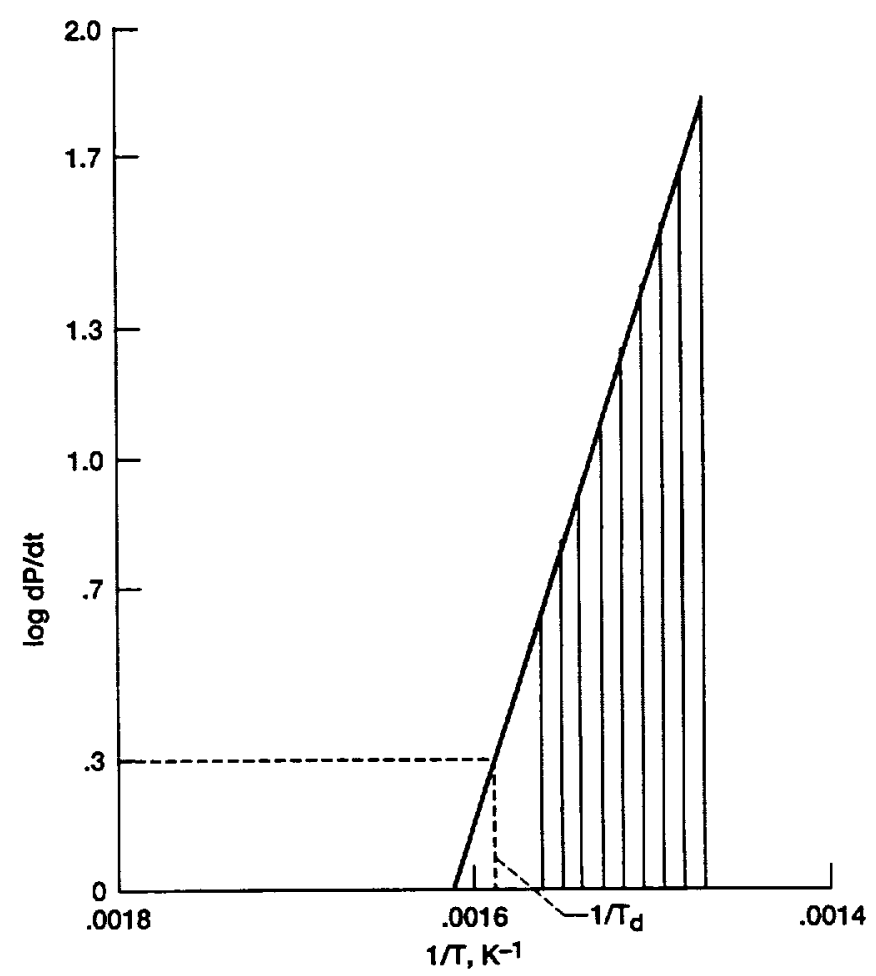

\begin{tabular}{|c|c|c|c|}
\hline Number & $\begin{array}{c}\text { Temperature, } \\
{ }^{\circ} \mathrm{C}\end{array}$ & $\mathrm{dP} / \mathrm{dt}$ & $\begin{array}{c}\mathrm{log}, \\
\mathrm{dP} / \mathrm{dt}\end{array}$ \\
\hline 1 & 365.0 & 4.338 & 0.6373 \\
2 & 370.2 & 6.074 & .7834 \\
3 & 375.1 & 7.809 & .8926 \\
4 & 380.3 & 12.14 & 1.0845 \\
5 & 385.1 & 15.61 & 1.1936 \\
6 & 390.4 & 25.16 & 1.4007 \\
7 & 395.5 & 34.70 & 1.5404 \\
8 & 400.3 & 48.59 & 1.6865 \\
9 & 405.5 & 72.02 & 1.8574 \\
\hline \multicolumn{3}{|c|}{$T_{d}=355.7^{\circ} \mathrm{C}$} \\
\hline
\end{tabular}

Figure 3.-Determination of $T_{d}$ for a poly(HFPO) fluid. 


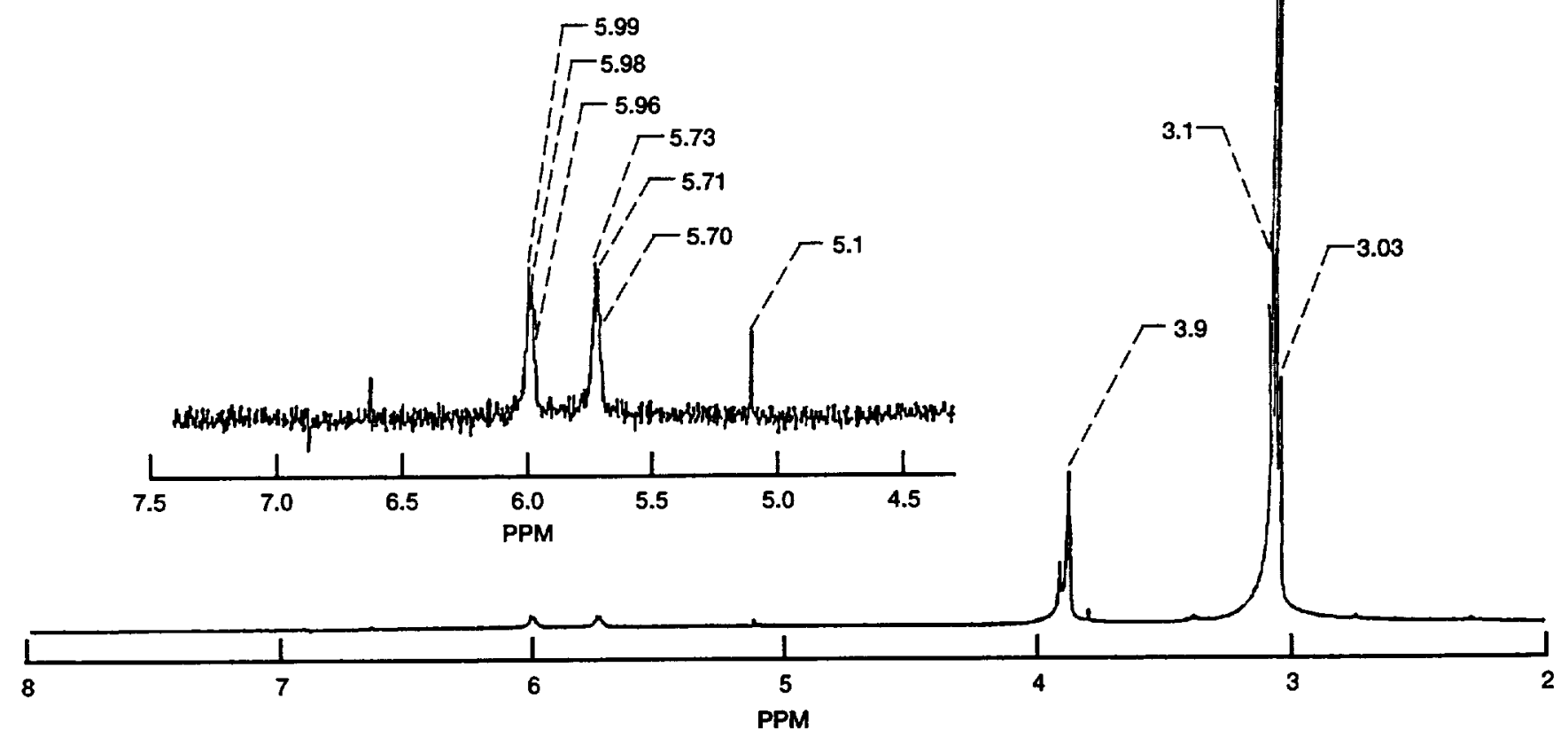

Figure 4. ${ }^{\mathbf{1}} \mathrm{H}$ NMR of AC fluid (as received). 


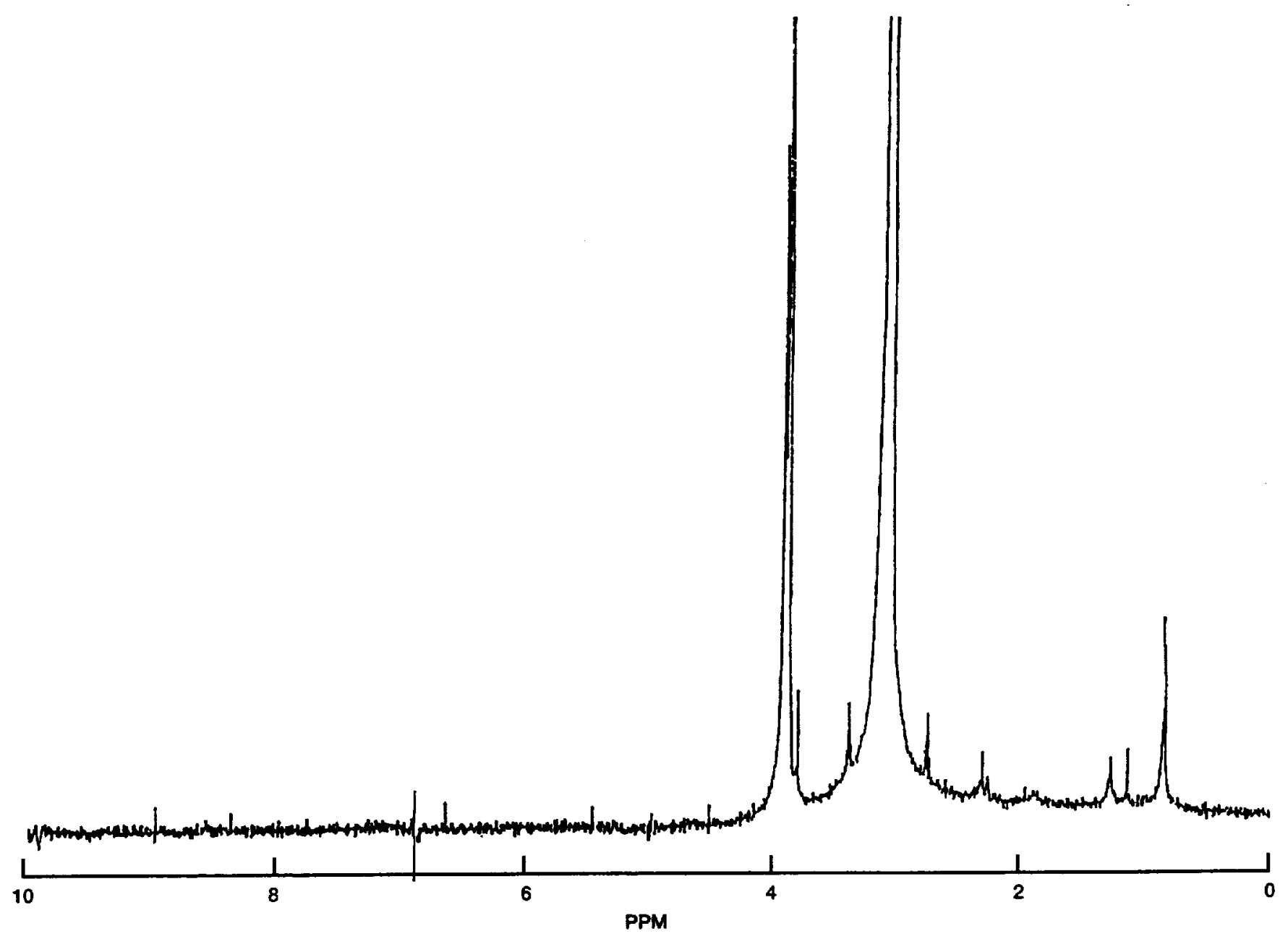

Figure 5.- ${ }^{1} \mathrm{H}$ NMR of AC fluid treated in $\mathrm{O}_{2}$ for $288 \mathrm{hrs}$ at $343^{\circ} \mathrm{C}$. 

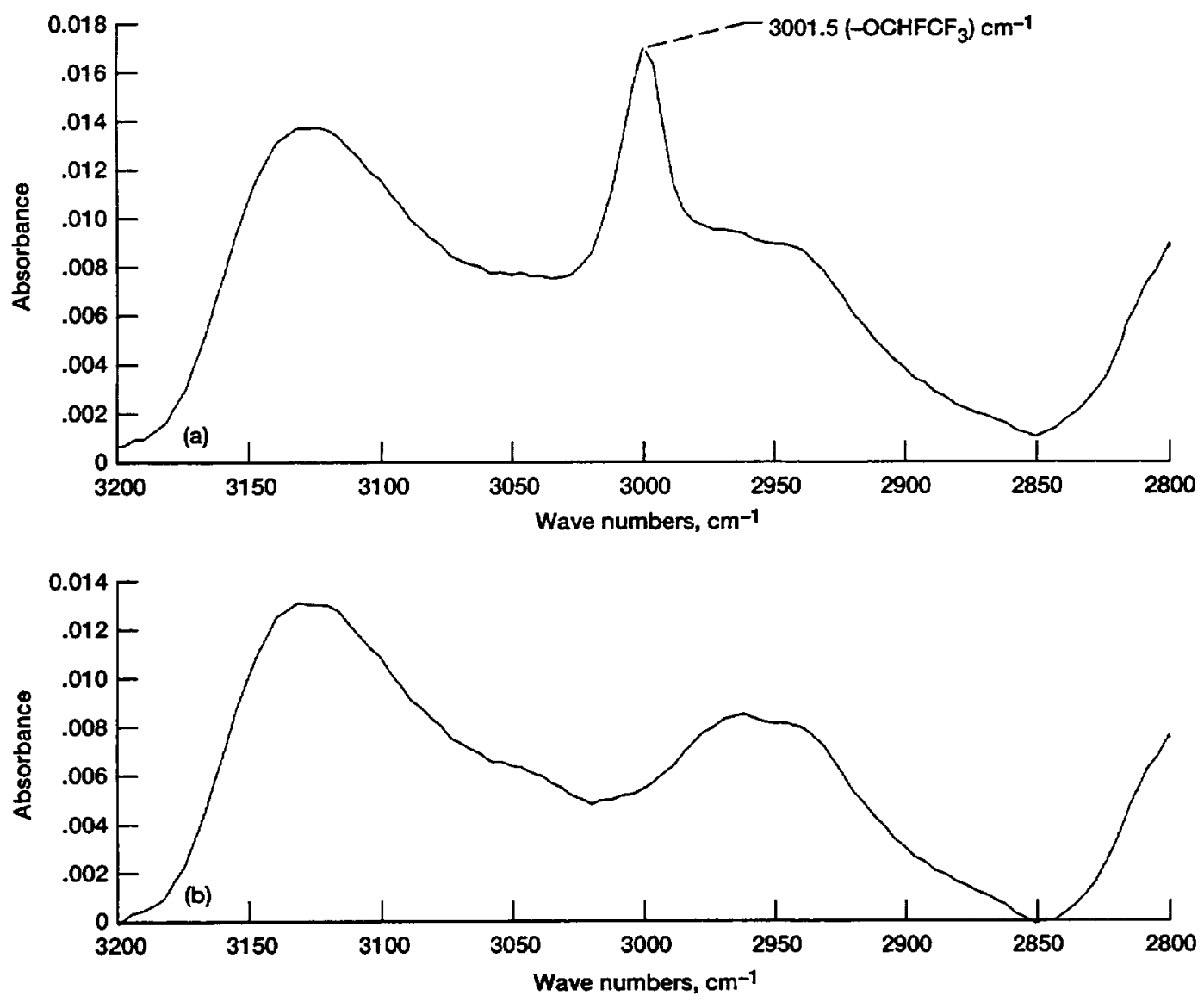

Figure 6.-Infrared spectra of AC fluid. (a) As received. (b) After pretreatment. 


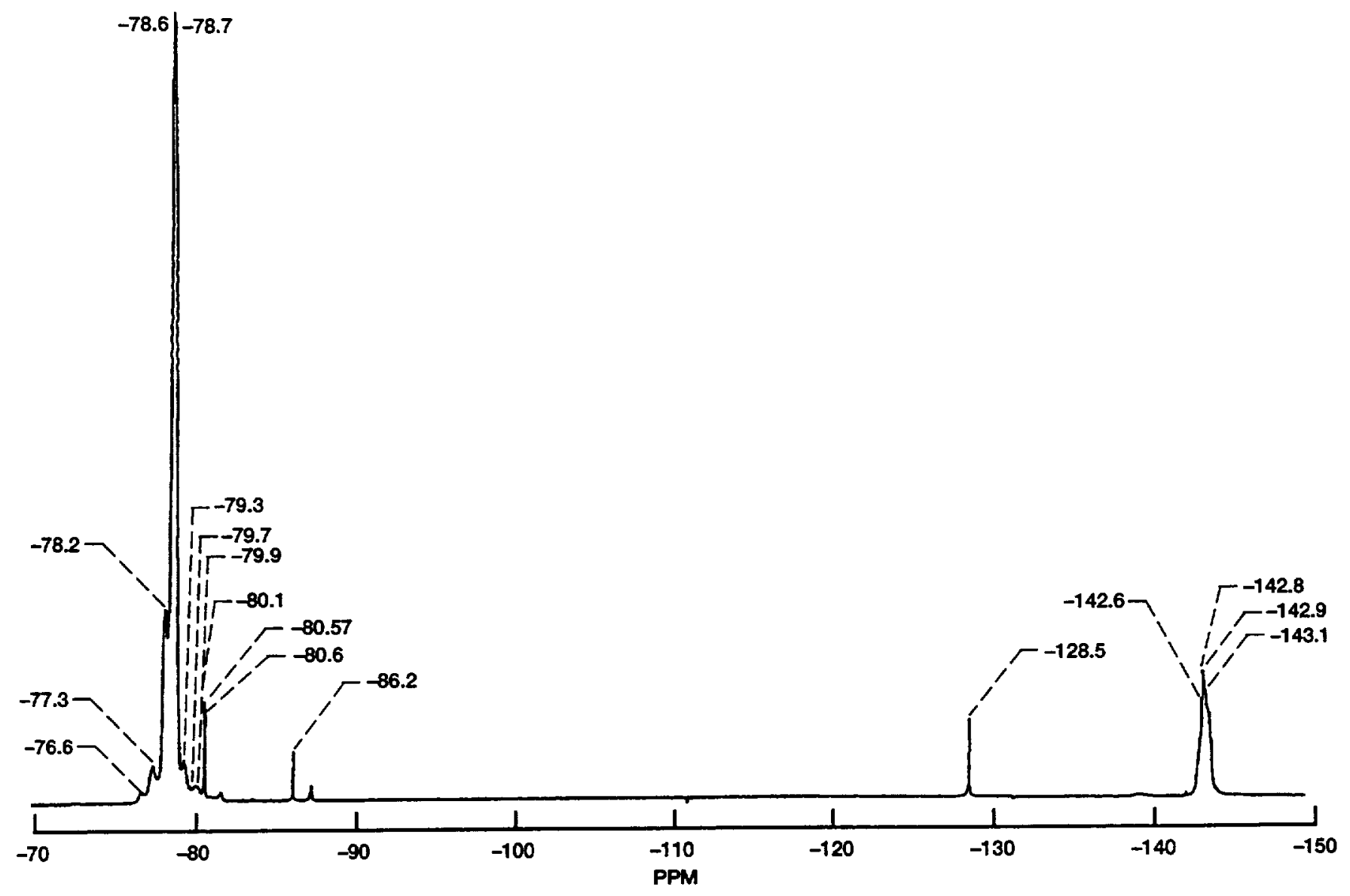

Figure 7. $-{ }^{19} \mathrm{~F}$ NMR of AC fluid (as received). 


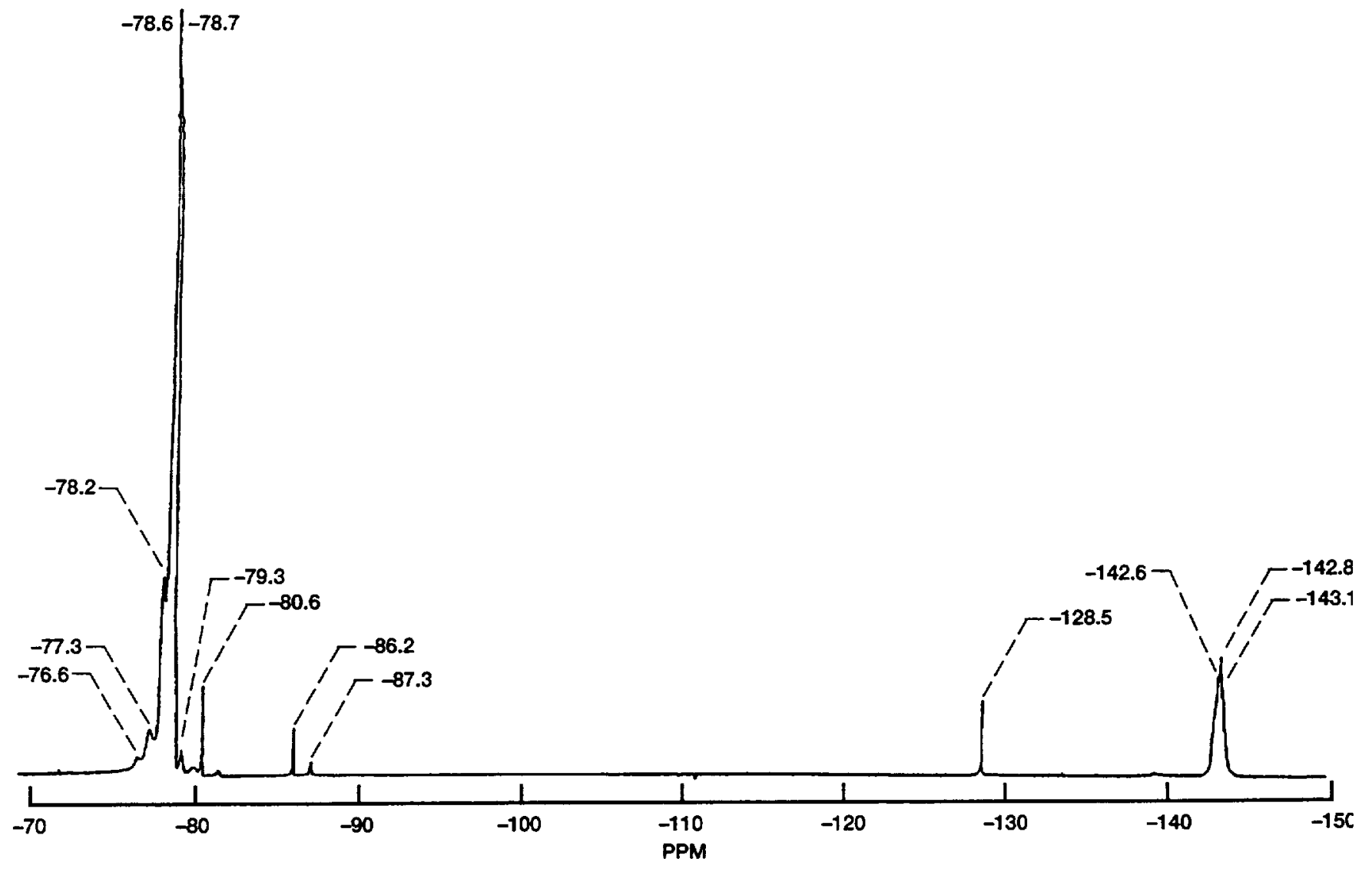

Figure 8. $-{ }^{19} \mathrm{~F} \mathrm{NMR}$ of AC fluid treated in $\mathrm{O}_{\text {, for }} 288$ hrs at $343^{\circ} \mathrm{C}$. 


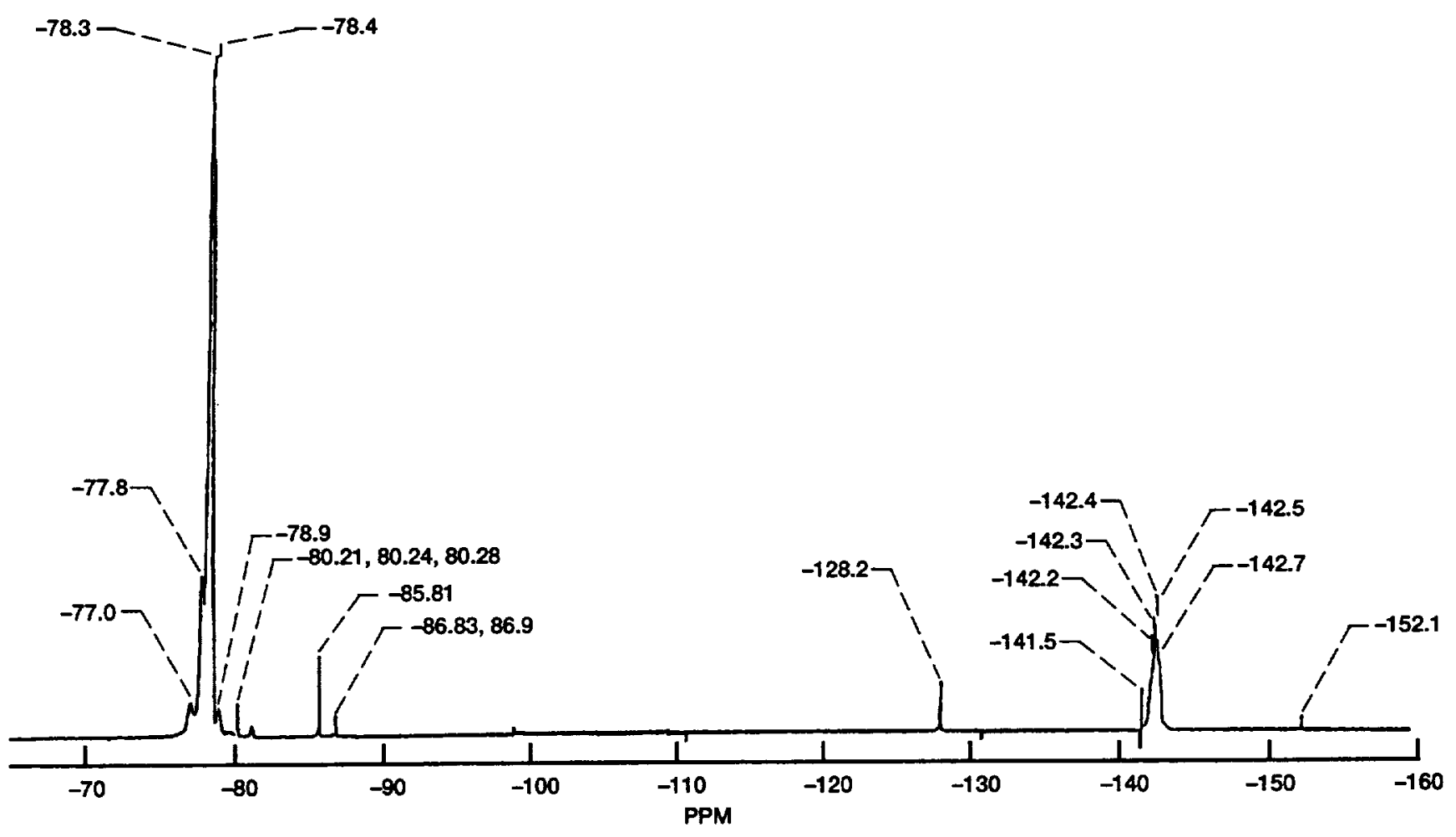

Figure 9.- ${ }^{19}$ F NMR of MLO-71-6 fluid as received (ref. 8). 

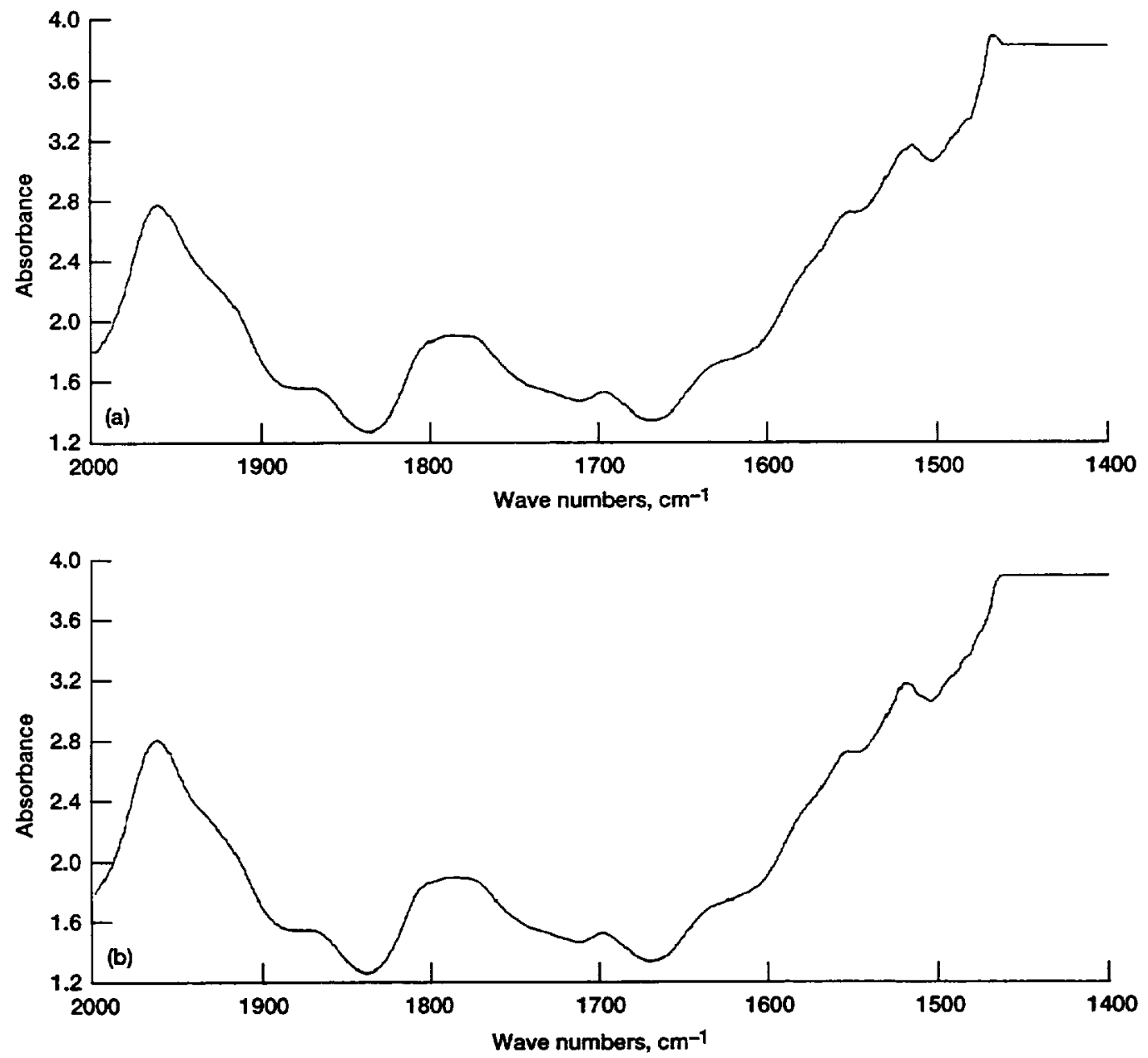

Figure 10.-Infrared spectra of AC fluid showing similarity of carbonyl region. (a) As received. (b) After pretreatment. 

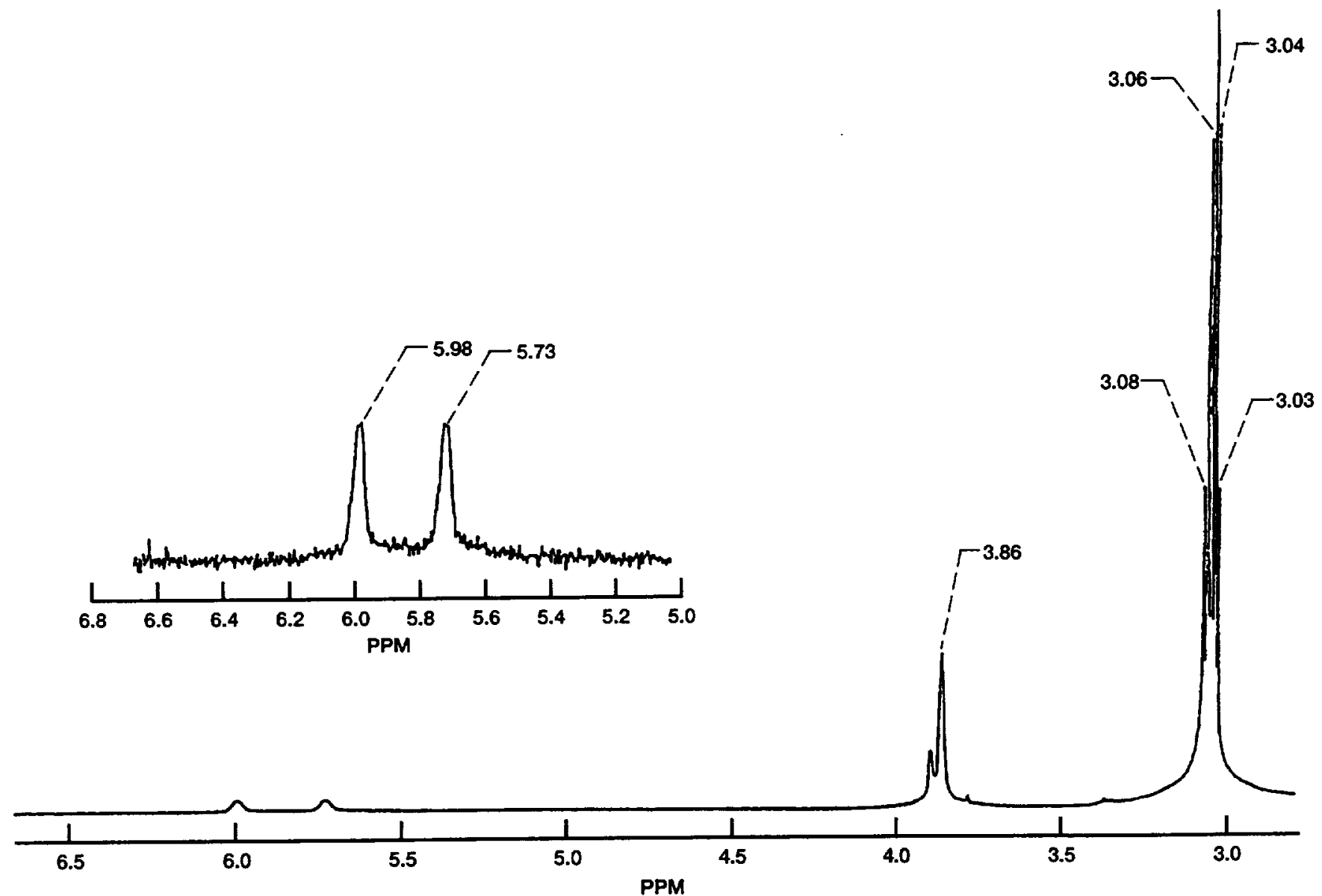

Figure 11. $-{ }^{1} H$ NMR of $A B$ fluid (as received). 


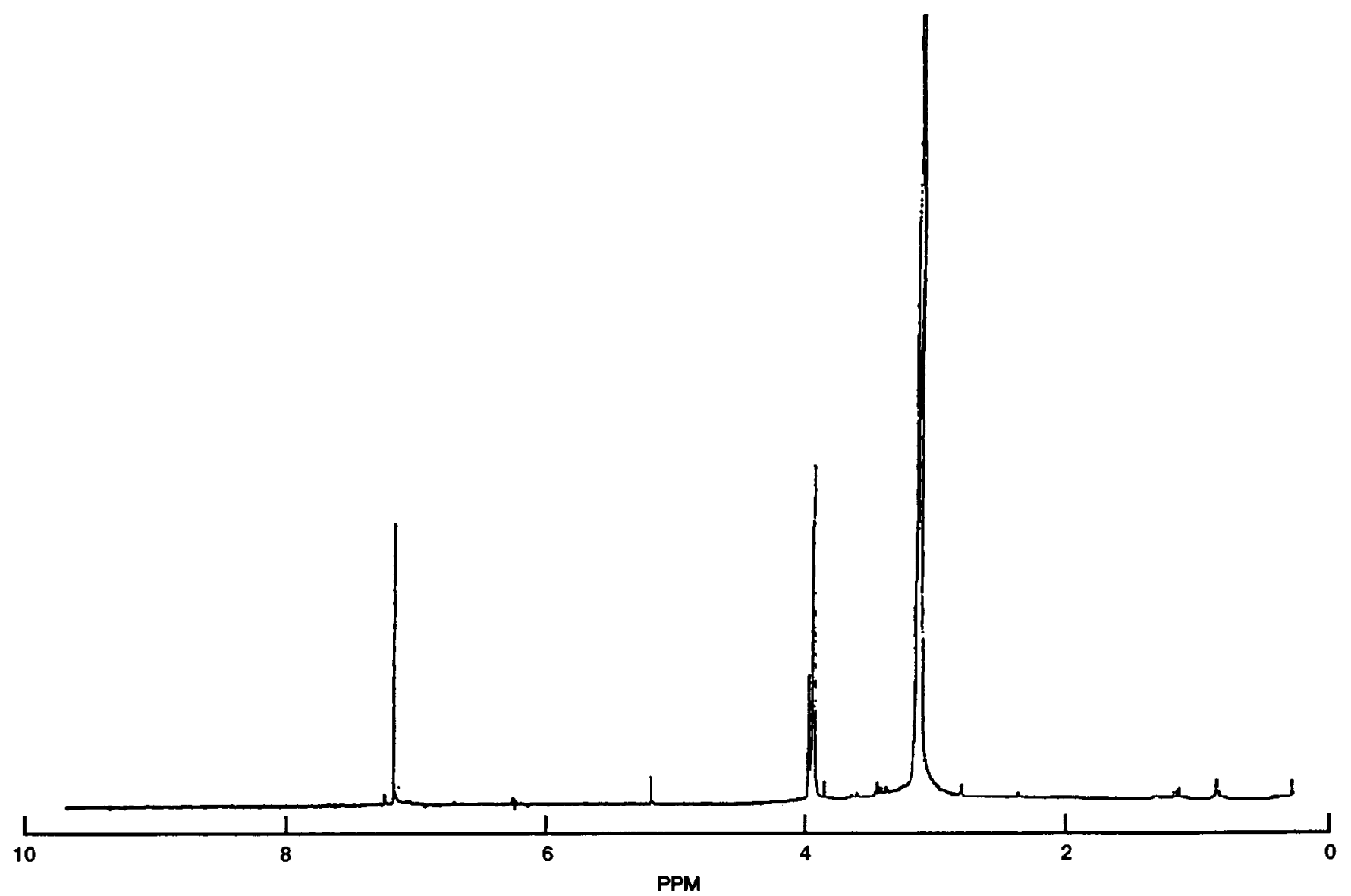

Figure 12. $-{ }^{1} \mathrm{H}$ NMR of AB fluid treated in $\mathrm{O}_{2}$ for $353 \mathrm{hrs}$ at $343^{\circ} \mathrm{C}$. 


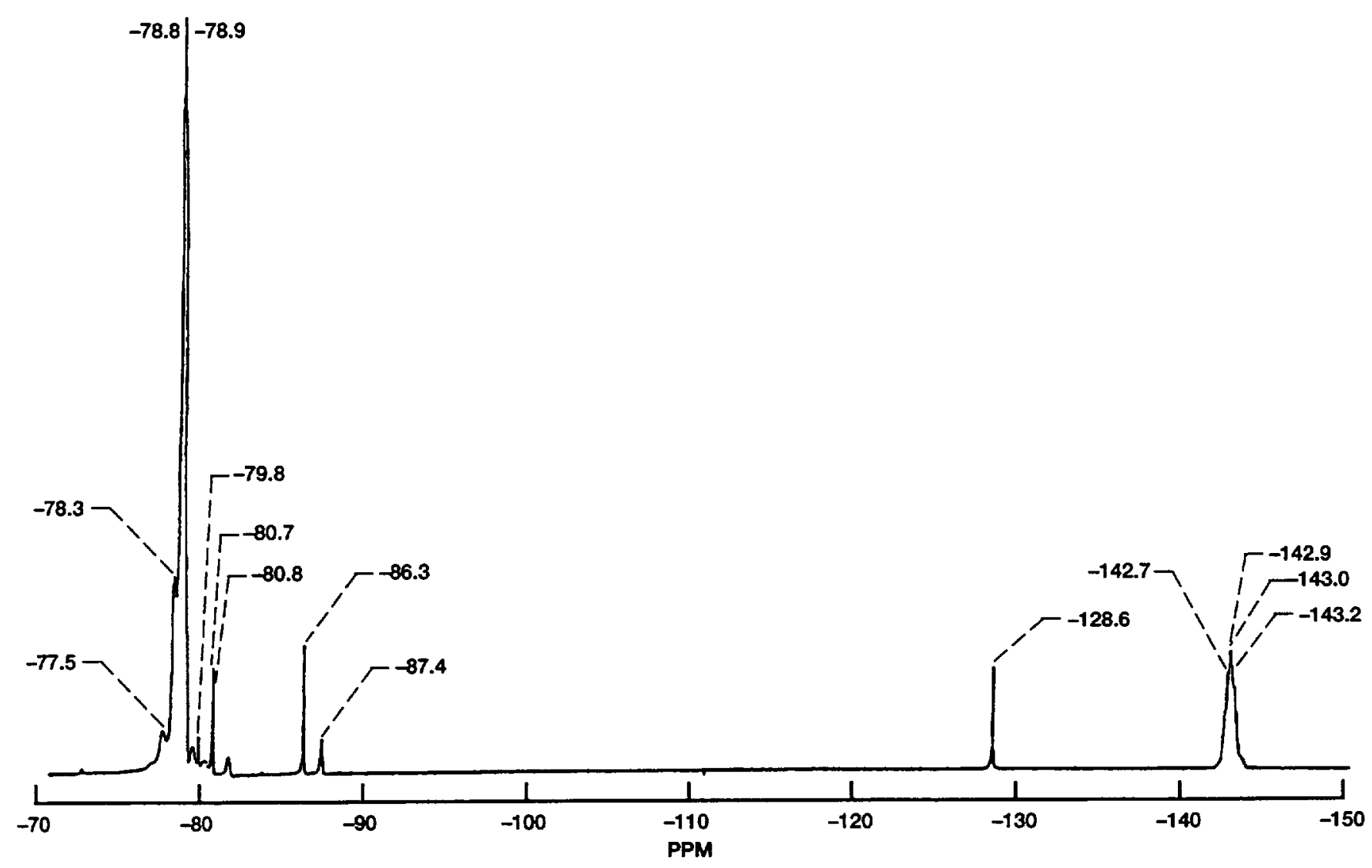

Figure 13. ${ }^{19}$ F NMR of AB fluid (as received). 

Public reporting burden for this collection of information is estimated to average 1 hour per response, including the time tor reviowing instructions, searching existing data sources, oathering and maintaining the data needed, and completing and reviewing the collection of inlormation. Send conments regarding this burden estimate $\alpha$ any other aspect of this collection of information, including suggestions for reducing this burden, to Washington Headquarters Services, Directorate for Inlormation Operations and Reports. 1215 Jefferson Davis Highway, Suhe 1204, Arlington, VA 22202-4302, and to the Office of Management and Budget, Papenwork Reduction Project (0704-0188), Washington, DC 20503.
1. AGENCY USE ONLY (Leave biank)
2. REPORT DATE
July 1994
3. REPORT TYPE AND DATES COVERED
Technical Memorandum

\section{TITLE AND SUBTITLE}

Thermal-Oxidative Pretreatment and Evaluation of Poly(Hexafluoropropene Oxide) Fluids

\section{AUTHOR(S)}

K.J.L. Paciorek, S.R. Masuda, W-H. Lin, W.R. Jones, Jr., and L.S. Helmick

\section{PERFORMING ORGANIZATION NAME(S) AND ADDRESS(ES)}

National Aeronautics and Space Administration

Lewis Research Center

Cleveland, Ohio 44135-3191

9. SPONSORINGMONITORING AGENCY NAME(S) AND ADDRESS(ES)

National Aeronautics and Space Administration

Washington, D.C. 20546-0001
5. FUNDING NUMBERS

WU-233-02-0D

8. PERFoRMING ORGANIzATION REPORT NUMBER

E-8974

10. SPONSORINGMONITORING AGENCY REPORT NUMBER

NASA TM-106659

11. SUPPLEMENTARY NOTES

Prepared for the Tribology Conference cosponsored by the Society of Tribologists and Lubrication Engineers and the American Society of Mechanical Engineers, Lahaina, Hawaii, October 16-19, 1994. K.J.L. Paciorek, S.R. Masuda, and W-H. Lin, Technolube Products Co., 3365 E. Slauson Ave., Vemon, California 90058; W.R. Jones, Jr., NASA Lewis Research Center; and L.S. Helmick, Cedarville College, Cedarville, Ohio 45314, and Summer Faculty Fellow at Lewis Research Center. Responsible person. W.R. Jones. Jr.. organization code 5140. (216) $433-6051$.

12a. DISTRIBUTIONAVAILABILITY STATEMENT

12b. DISTAIBUTION CODE

Unclassified - Unlimited

Subject Category 27

13. ABSTAACT (Maximum 200 words)

Two commercial poly(hexafluoropropene oxide) fluids were thermally pretreated at $343^{\circ} \mathrm{C}$ in pure oxygen. IR and NMR spectra indicate that this pretreatment was effective in removing hydrogen end-capped impurities. Decrease in the quantity of volatile material produced during thermal oxidative decomposition and increase in the thermal decomposition temperature indicated improvement in the stability of the fluids. However, this pretreatment failed to render the fluids completely stable in oxidizing atmospheres at $316^{\circ} \mathrm{C}$ in the presence of metal alloys.

\begin{tabular}{l} 
14. SUBJECT TERMS \\
Lubricants; Perfluoropoly \\
\hline $\begin{array}{l}\text { 17. SECUAITY CLASSIFICATION } \\
\text { OF REPORT } \\
\text { Unclassified }\end{array}$
\end{tabular}

NSN 7540-01-280-5500

18. SECURITY CLASSIFICATION
OF THIS PAGE
Unclassified

19. SECURITY CLASSIFICATION OF ABSTRACT Unclassified
15. NUMBER OF PAGES 20

16. PRICE CODE $\mathrm{AO} 3$

\section{LMITATION OF ABSTRACT}

